\title{
EXPERIENCE OF INTERNAL AND EXTERNAL EDUCATION QUALITY RATE: ESG AND THE LEGISLATION OF THE RUSSIAN FEDERATION
}

\author{
Ivan N. Nikanorov ${ }^{1, *}$, and Svetlana V. Volkova ${ }^{2}$ \\ ${ }^{1}$ The Ministry of Education and Science Council's youth affairs' education quality commission of \\ Russian Federation, Moscow \\ ${ }^{2}$ Candidate of Sciences (Pedagogics) (PhD), The Ministry of Education and Science Council's youth \\ affairs' education quality commission of Russian Federation, Moscow
}

\begin{abstract}
Overview of regulation of internal and external education quality rate has been presented. The development of regulation an independent assessment of higher education in Russia in the context of ESG has been considered. Authors noticed, that instruments of internal and external quality rate interact in Russian legislation insufficiently.
\end{abstract}

\section{Introduction}

Rapid changes in the world over the past 20-30 years have particularly transformed the global economy, radically changing the requirements for personnel training and, relatively, for the higher education system. The formation of "lifelong learning" conception has become a solemn challenge for the traditional institutions and the educational management principles.

Common problems and challenges inherent to a numerous systems of higher education, among which are countries of Western and Eastern Europe, as well as some countries in Asia and CIS, have determined the necessity of corporate solutions to form an integrated area that provides a mutual educational levels recognition, quality assurance along with the expansion of its availability.

The creation of European Higher Education Area (EHEA) has become the result of these mutual efforts after the Declaration at the conference in Budapest - Vienna in March 2010 was signed. It currently includes 48 participating countries.

One of the key documents organizing the establishment of unified principles of the higher education quality in the designated area has become "Standards and Guidelines for Quality Assurance in the European Higher Education Area“ (ESG) [1]. This document has been adopted by the conference of Ministers, responsible for Higher Education of EHEA, in Yerevan on May 14-15, 2015.

\section{Results}

\footnotetext{
* Corresponding author: nikanorov@zaobrazovanie.ru
} 
It has added opportunities for participation of educational institutions in international projects and expanded mutual cooperation. It has also introduced new principles of educational process for many educational systems, in particularly in Russia these are "student-centered learning" and "on-going monitoring and periodic review of programs". The European Students Union, which is a recognized member of the European education quality assurance system, actively involves students in the assessment mechanisms and the "internal quality insurance" of educational institutions. With the goal of developing student feedback tools and to improve quality of education, The European Students Union has become one of the key developers of "Standards and Guidelines for Quality Assurance in the European higher Education Area"(ESG).

The system of professional certification of qualifications and independent assessment of education quality based on the activities of professional communities is an essential guarantee for the independent education quality assessment of personnel training systems of the countries participating in the EHEA.

Thus, the European higher education area (EHEA) provides a complex self-developing system of the education quality assessment based on student-centered principles, based on independence and transparency.

In this regard, let us consider the development of Russian national legislation in the field of education that has formed the background for the devolvement of practices of involving students in the assessment of the education quality. The reforms of Russian higher education system within the last decade has been aimed at gradual transition to the competitive development of educational institutions. In this respect, each educational institution of higher education has received greater autonomy and, accordingly, greater responsibility within the Federal law from December 29, 2012 No. 273-FZ "On education in the Russian Federation", which came into force on 1 September 2013[2].

The development of the higher education system is impossible without creating multilevel tools of assessing the effectiveness and quality of education. Legal framework of formation of the system are defined by the above-mentioned Federal law as well as by the Federal law of July 21, 2014 № 256-FZ “On amendments to certain legislative acts of the Russian Federation on the point of independent evaluation of service delivery by the organizations in the sphere of culture, social services, health and education" (came into force on October 21, 2014) [3].

In this regard, the changes of article 95.1 "Independent evaluation of the quality of training of students“ № 273-FL "On education in the Russian Federation" were adopted. It stated that "independent assessment of the quality of students training is held at the initiative of participants of relations in the sphere of education with the aim of preparing information about the level of mastering of the educational program or its parts, as well as providing the participants of relations in the sphere of education with information about the quality of training“.

It is noteworthy that the coordination of activities and general methodological support of independent assessment of quality of services in the field of education is realized by the Federal Executive body, responsible for drafting and implementing state policy and legal and regulatory framework in the sphere of social protection for the public (Ministry of Labour and Social Development of the Russian Federation), in the order established by the Government of the Russian Federation. Earlier, in the context of absence of established mechanisms of legal regulation of this issue, the Federal executive authorities responsible for public policy in education (Ministry of Education and Science of the Russian Federation), carried out this activity independently on the basis of expediency.

Along with this, there is formed the system of professional-public accreditation, directly focused on the involvement of employers in assessing the quality of higher education. Its results can be considered by the founder of the higher education organization in making 
management decisions, including allocation of control figures of enrolment of students for training at the expense of budgetary appropriations of the Federal budget (CFE). Control figures of enrolment serve as an indicator of the demand for graduates of educational programs of higher education by employers in the eyes of potential applicants. In the emerging space of professional-public accreditation, the most notable associations are the Association of Russian Lawyers (AYUR), the Federation of Restaurateurs and Hoteliers, Opora of Russia, the Association of Managers of Russia and others. However, it should be noted that not all of the integrated groups of specialties have associations of employers that are interested in conducting qualified professional-public accreditation. The current practice of conducting professional-public accreditation allows to note that the criteria used by associations of employers are completely different criteria database and evaluation mechanisms, which makes it difficult to unify and correlate of the results of different accreditation procedures.

Thus, the legislator forms a system of education quality assessment oriented not primarily to the state education authorities, but to employers and their associations. Now that the assessment system of education quality by employers is in its infancy, it can be assumed that its regular functioning is a matter of long-term prospects.

Further development of legal regulation on this issue is expressed in the Federal law "On the independent assessment of qualification" from 03.07.2016 N 238-FZ [4] that has not come in force yet. The rules of this act assume full transfer of responsibility for certification of qualifications to employers and authorized centers of the qualifications completely excluding educational organizations and the academic community from the procedures. The implementation of this law is still a matter of debate among experts, as well as its correlation with the labor legislation of the Russian Federation.

\section{Conclusion}

In the framework of existing educational system there has formed a clear understanding of the necessity of assessment of the higher education system, not only external (public and expert) assessment, but also the internal one that expresses the opinion of the student community in respect of quality of educational services received. The analysis takes into consideration not only the work of the faculty, but also the satisfaction of the students with the conditions and results of education. Final results of the assessment are subsequently considered in the system of indicators of efficiency of higher educational institutions.

Only a system based on the maximum involvement of all the parties can solve socialcultural problems that Russian education faces. In this regard, it is most desirable to develop the system of shared government and public administration in the education system by developing the activities of the representative bodies of direct participants of the educational process, of students in particular.

All-Russian public organization "For quality education" in the framework of the international youth project "Involvement of students in evaluating and improving the quality of education" has formed a strong model for collaboration between student associations, the faculty and administration of educational institutions, aimed at improving the quality of education through the mechanisms of the internal assessment.

Thus, it should be noted that along with the development of the system of independent assessment of qualifications it is necessary to have tools for the development of internal education quality assessment, which will help to harmonize the interests of all stakeholders in the education system, as well as enhance the integration of the Russian Federation in the European higher education area (EHEA). 


\section{References}

1. Standards and Guidelines for Quality Assurance in the European Higher Education Area (ESG) (Brussels, Belgium, 2015).

2. Federal Law 273-FZ, dated 29 December, "On education in the Russian Federation“, 2012.

3. Federal Law 256-FZ, dated 21 July, "On amendments to certain legislative acts of the Russian Federation on the point of independent evaluation of service delivery by the organizations in the sphere of culture, social services, health and education", 2014.

4. Federal Law 238-FZ, dated 3 July, "On the independent assessment of qualification", 2016. 